\title{
LONG-TERM NATURAL FLOW REGIME (SPELLS) ANALYSIS FOR WATER TREATMENT DISCHARGES
}

\author{
O. Makarynskyy, D. Makarynska
}

\author{
Metocean Dynamic Solutions, \\ 9 Seale Street, Fannie Bay,0820 NT, Australia, makarynskyy@outlook.com
}

\begin{abstract}
Conducting mineral extraction activities usually requires obtaining a set of permits for each of the activities planned to be undertaken. This directly concerns water management and discharges associated with any mineral extraction operations. In response to the growing demand for energy resources worldwide, the industry demand for permits relating to the extraction of coal seam (and shale) gas also increased dramatically. This was in turn accompanied by the growing community concerns in regard to fracking and wastewater management practices.

To address these concerns, the state governments in Australia developed a strict framework and guidelines for the permit application process and provided terms of reference for the environmental impact assessments, where required. In accord with the guidelines, a liquefied natural gas mining operator was conducting a research to assess several facets of water releases from Reedy Creek Water Treatment Facility to Yuleba Creek in Queensland. The scope for the research was developed in line with such guidelines and included estimating the downstream extents of flows from several Water Treatment Facility discharge volumes over a period of planned discharges. More specifically, the purpose of the study presented in this paper was to assess flows in Yuleba Creek before and after the proposed releases of treated water from the Reedy Creek Water Treatment Facility, and how the planned change to flow parameters would satisfy the regulatory guidelines. The assessment was based on 41 years of data collected at the Forestry Station gauge.

An analysis of the obtained results suggested that the historical maximum was $25,825 \mathrm{ML} / \mathrm{d}$. An analysis of the median flows suggested that the years 1983, 1999, and 2010-2012 had the highest medians of around $15 \mathrm{ML} / \mathrm{d}, 10 \mathrm{ML} / \mathrm{d}$, and from $9 \mathrm{ML} / \mathrm{d}$ to $12 \mathrm{ML} / \mathrm{d}$ respectively. The median flow values would exceed from $0.09 \mathrm{ML} / \mathrm{d}$ to $0.69 \mathrm{ML} / \mathrm{d}$ flows during the months of February and March only. The lowest 90th percentile flows were obtained for the months from April through to October. The highest flow estimates would be in the months from November through to March. An analysis of the flow duration curves suggested that the annually averaged flow of $0.08 \mathrm{ML} / \mathrm{d}$ in the Yuleba Creek would be present for around $48 \%$ of the time. Flows predictabilities were calculated; for the baseline flow records, the value of predictability was 0.50 , and the constancy/predictability ratio was 0.89 . The rates of streamflow rise and fall were estimated and analysed. The results suggested that the rate of streamflow rise varied within a range from 0.0 up to $320.0 \mathrm{ML} / \mathrm{d}$ per day. The rates of streamflow fall was up to $15.0 \mathrm{ML} / \mathrm{d}$ per day.

Key words: coal seam gas extraction; water management; flow parameters; magnitude of flows; variability of flows; flow predictability; rates of rise and fall for increased flows
\end{abstract}

\section{INTRODUCTION}

This is a worldwide practice to obtain permits from relevant government levels and authorities for conducting and managing mineral extraction activities. This specifically concerns water management and discharges associated with such activities. In recent years, the industry demand for permits relating to the extraction of coal seam (and shale) gas increased dramatically. The growing demand for permits was accompanied by the accordingly growing community concerns in regard to fracking and wastewater management practices.

To address the growing concerns, the state gov- ernments in Australia developed a strict framework and guidelines for the permit application process and provided terms of reference for the environmental impact assessments, where required. In accord with the guidelines and specific for the project terms of reference, a liquefied natural gas mining operator was conducting a research to assess several facets of water releases from Reedy Creek Water Treatment Facility to Yuleba Creek in Queensland. The scope for the research was developed in line with [1] as required by the Queensland government.

The scope included estimating the downstream 
extents of flows from several Water Treatment Facility discharge volumes over a period of planned discharges. More specifically, the purpose of the study presented in this paper was to assess flows in Yuleba Creek before and after the proposed releases of treated water from the Reedy Creek Water Treatment Facility, and how the planned change to flow parameters would satisfy the regulatory guidelines. The study focused on estimating the downstream extents of flows from several Water Treatment Facility discharge volumes over a period of six month.

\section{USED DATA}

The data considered in these analyses were obtained from the gauge 422219A - Yuleba Creek at Forestry Station (Latitude 26.8474 S, Longitude 49.4724 E, http://watermonitoring.derm.qld.gov.au). These were the daily discharge records covering a 41-year period, from January 1973 through to December 2013.

Three different time series were considered in the analyses:

- Forestry Station; the gauge records for the Yuleba Creek catchment area from the upper reaches down to the gauge location (sub-areas from A through to E in Figure 1) were processed,

- Middle Station; the Forestry Station gauge records scaled (divided) by the factor of 1.9 to reflect the decrease of the catchment (covered by sub-areas from A through to D in Figure 1) by the mentioned factor were processed to reflect flows at this site,

- Discharge Site; the Forestry Station gauge records scaled by the factor of 71.4 in accord to the decreased catchment (sub-area A in Figure 1) were processed to estimate flows at this site.

\section{ASSESSED FLOW CHARACTERISTICS}

To assess the natural creek flow regime, as well as how the flow regime will change after $40 \mathrm{ML} / \mathrm{d}$ discharge added to the flow, the following characteristics were estimated:

- Magnitude of flows,

- Variability of flows,

- Duration of increased flow impacts,

- Timing of increased flow impacts,

- Flow predictability

- Rates of rise and fall for increased flows.

The methodology applied to evaluate the above characteristics was the natural flow regime analysis. There were a number of publications on this topic starting from the earliest editions of [2], which was in part based on [3] as well as other published to

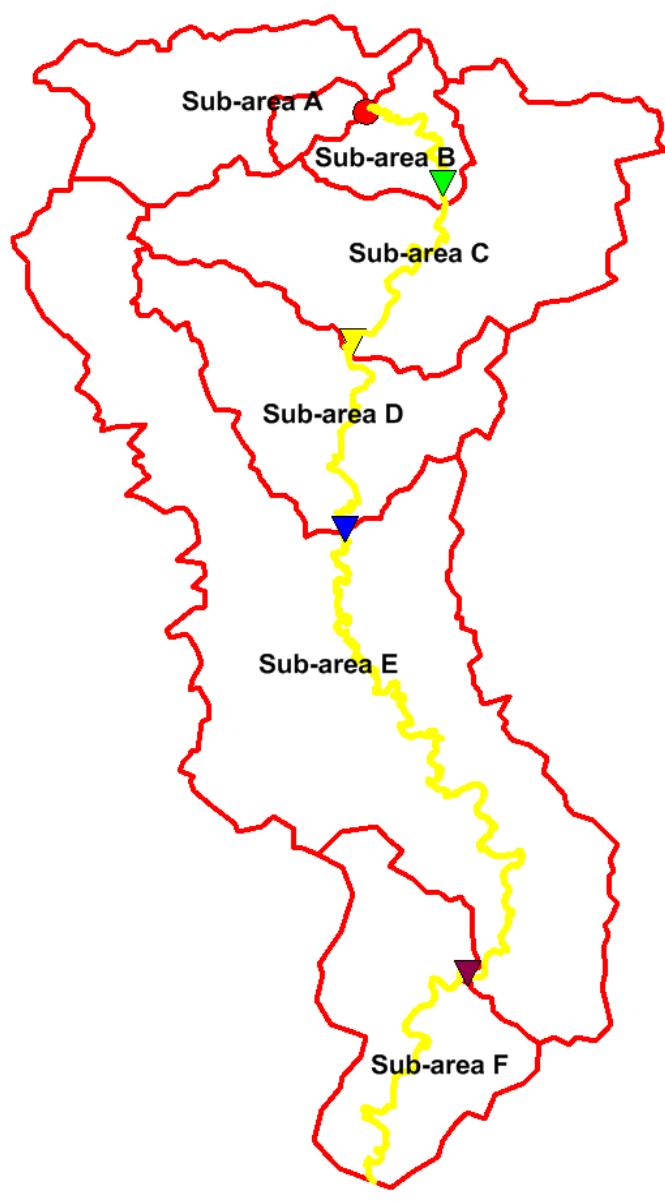

Figure 1 - Sub-areas of Yuleba Creek catchment; Discharge Site is marked by circle between Sub-area A and Sub-area B, Middle Station is marked by triangle between Sub-area D and Sub-area E, Forestry Station is marked by triangle between Subarea $\mathrm{E}$ and Sub-area $\mathrm{F}$

that date research. The Spells Analysis methodology was then further developed and implemented in Australia by e.g. [4] and [5]. It has been demonstrated in a number of publications that the methodology may be used for creeks as well as entre river basins [6-7].

\section{OBTAINED RESULTS}

\subsection{Magnitudes}

To analyse flow magnitudes and how they would change with a $40 \mathrm{ML} / \mathrm{d}$ discharge coming from the Reedy Creek WTF, maximum daily Yuleba Creek discharges at the Forestry Station, Middle Station and Discharge Site were plotted for years 19732013 (Figure 2) and the same discharges plus $40 \mathrm{ML} / \mathrm{d}$ (Figure 3).

An analysis of the figures suggest that considering the historical maximum value of $25,825 \mathrm{ML} / \mathrm{d}$ in the year of 1996 at the Forestry Station, the contribution from the WTF of around $0.2 \%$ of the maximum would not be discernable. At the Middle 


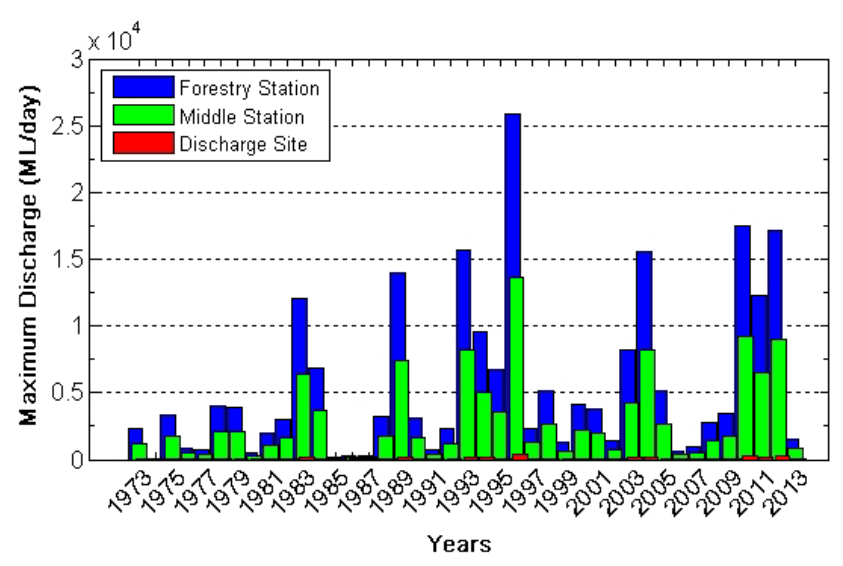

Figure 2 - Maximum daily discharges estimated at three study locations

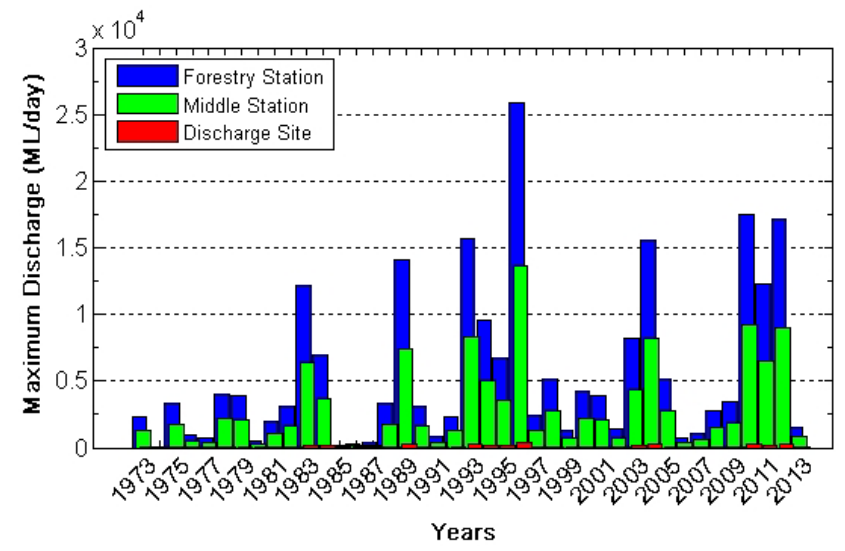

Figure 3 - Maximum daily discharges accounting for $40 \mathrm{ML} / \mathrm{d}$ discharge from Reedy Creek WTF estimated at three study locations

Station, the estimated historical maximum was around $13,591 \mathrm{ML} / \mathrm{d}$; the contribution from the WTF would be around $0.3 \%$. At the Discharge Site, the estimated historical maximum was around $362 \mathrm{ML} / \mathrm{d}$ and the contribution from the WTF discharge would be $11.1 \%$.

To better evaluate flow magnitudes and their variability, as well as estimate probable changes to the flow regime due to a $40 \mathrm{ML} / \mathrm{d}$ discharge from the Reedy Creek WTF, median Yuleba Creek discharges were also plotted (Figure 4 and Figure 5). An analysis of the medians at the Forestry Station suggest that the years 1983, 1999, and 2010-2012 had the highest medians of around $15 \mathrm{ML} / \mathrm{d}$, $10 \mathrm{ML} / \mathrm{d}$, and from $9 \mathrm{ML} / \mathrm{d}$ to $12 \mathrm{ML} / \mathrm{d}$ respectively. At the Middle Station and Discharge Site, the medians were lower, in accord with the catchment scaling coefficients.

For 30 out of 41 years, the median discharges evaluated from the historical records were $0 \mathrm{ML} / \mathrm{d}$, and for the rest they did not exceed $3 \mathrm{ML} / \mathrm{d}$. When there are $40 \mathrm{ML} / \mathrm{d}$ added on top of the historical data, the historical medians all increase by this value (Figure 5).

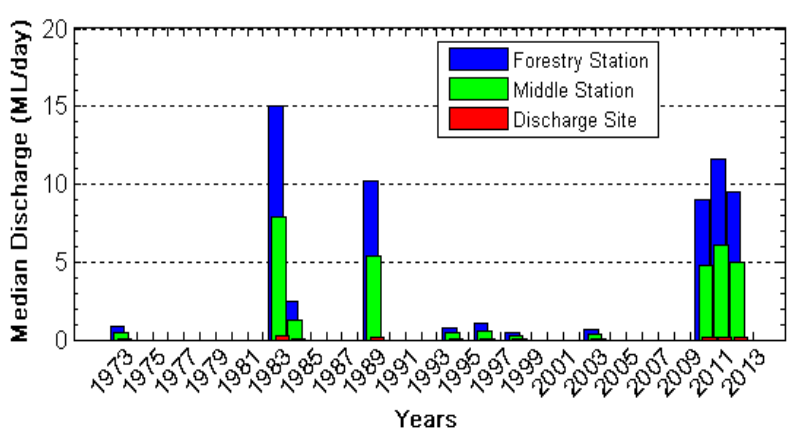

Figure 4 - Median discharges estimated at three study locations

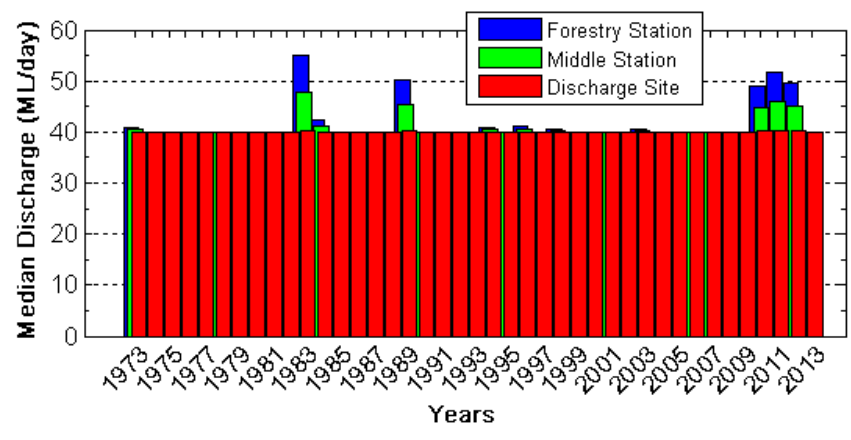

Figure 5 - Median daily discharges accounting for $40 \mathrm{ML} / \mathrm{d}$ discharge from Reedy Creek WTF estimated at three study locations

\subsection{Variability, duration and timing}

To evaluate flow variability at different locations along the Yuleba Creek extent, 5th, 50th, 75th, 90th and 95th percentiles of the historical records of daily flows were calculated for the Forestry Station, Middles Station and Discharge Site locations. The statistics are presented in Table 1, Table 2 and Table 3 respectively.

An analysis of the tables suggests that the 5th percentile was 0 each month at all three sites.

The median values (or the 50th percentile) would exceed from $0.01 \mathrm{ML} / \mathrm{d}$ (at the Discharge Site, Table 3) to $0.69 \mathrm{ML} / \mathrm{d}$ (at the Forestry Station, Table 1) during the months of February and March only.

The 75th flow percentiles would range from $1.02 \mathrm{ML} / \mathrm{d}$ (June, Table 1) to $32.25 \mathrm{ML} / \mathrm{d}$ (February, Table 1) at the Forestry Station; from $0.53 \mathrm{ML} / \mathrm{d}$ to 16.97 ML/d at the Middle Station (Table 2); and from $0.01 \mathrm{ML} / \mathrm{d}$ to $0.45 \mathrm{ML} / \mathrm{d}$ at the Discharge Site (Table 3). The lowest 75 th percentiles were obtained for the months from April through to November (up to $4.15 \mathrm{ML} / \mathrm{d}$ in September (Table 1) at the Forestry Station, up to $2.18 \mathrm{ML} / \mathrm{d}$ at the Middle Station, and up to $0.06 \mathrm{ML} / \mathrm{d}$ at the Discharge Site), while the highest values would be for the months of December through to March (from $21.77 \mathrm{ML} / \mathrm{d}$ at the Forestry Station; from $11.46 \mathrm{ML} / \mathrm{d}$ at the Middle 
Table 1 - Flow percentiles (ML/d) at Forestry Station

\begin{tabular}{|c|c|c|c|c|c|c|}
\hline № & Month & $\begin{array}{c}5 \text { th } \\
\text { \%ile }\end{array}$ & $\begin{array}{c}50 \text { th } \\
\text { \%ile }\end{array}$ & $\begin{array}{c}75 \text { th } \\
\text { \%ile }\end{array}$ & $\begin{array}{c}\text { 90th } \\
\text { \%ile }\end{array}$ & $\begin{array}{c}\text { 95th } \\
\% \text { ile }\end{array}$ \\
\hline 1. & Jan & 0.00 & 0.00 & 25.81 & 247.74 & 702.26 \\
\hline 2. & Feb & 0.00 & 0.69 & 32.25 & 211.87 & 736.37 \\
\hline 3. & Mar & 0.00 & 0.09 & 21.77 & 94.64 & 432.65 \\
\hline 4. & Apr & 0.00 & 0.00 & 1.64 & 26.78 & 126.90 \\
\hline 5. & May & 0.00 & 0.00 & 2.46 & 22.76 & 76.31 \\
\hline 6. & Jun & 0.00 & 0.00 & 1.02 & 17.88 & 55.58 \\
\hline 7. & Jul & 0.00 & 0.00 & 1.27 & 20.70 & 50.29 \\
\hline 8. & Aug & 0.00 & 0.00 & 1.73 & 20.71 & 57.37 \\
\hline 9. & Sep & 0.00 & 0.00 & 4.15 & 30.84 & 65.38 \\
\hline 10. & Oct & 0.00 & 0.00 & 1.30 & 11.51 & 42.34 \\
\hline 11. & Nov & 0.00 & 0.00 & 3.24 & 61.00 & 293.59 \\
\hline 12. & Dec & 0.00 & 0.00 & 26.81 & 176.41 & 1012.26 \\
\hline
\end{tabular}

Table 2 - Flow percentiles (ML/d) at Middle Station

\begin{tabular}{|l|c|c|c|c|c|c|}
\hline № & Month & $\begin{array}{c}5 \text { th } \\
\text { \%ile }\end{array}$ & $\begin{array}{c}50 \text { th } \\
\text { \%ile }\end{array}$ & $\begin{array}{c}75 \text { th } \\
\text { \%ile }\end{array}$ & $\begin{array}{c}90 \text { th } \\
\% \text { ile }\end{array}$ & $\begin{array}{c}95 \text { th } \\
\text { \%ile }\end{array}$ \\
\hline 1. & Jan & 0.00 & 0.00 & 13.59 & 130.36 & 369.60 \\
\hline 2. & Feb & 0.00 & 0.36 & 16.97 & 111.54 & 387.56 \\
\hline 3. & Mar & 0.00 & 0.05 & 11.46 & 49.81 & 227.69 \\
\hline 4. & Apr & 0.00 & 0.00 & 0.86 & 14.10 & 66.79 \\
\hline 5. & May & 0.00 & 0.00 & 1.30 & 11.98 & 40.16 \\
\hline 6. & Jun & 0.00 & 0.00 & 0.53 & 9.41 & 29.25 \\
\hline 7. & Jul & 0.00 & 0.00 & 0.67 & 10.90 & 26.47 \\
\hline 8. & Aug & 0.00 & 0.00 & 0.91 & 10.90 & 30.19 \\
\hline 9. & Sep & 0.00 & 0.00 & 2.18 & 16.23 & 34.41 \\
\hline 10. & Oct & 0.00 & 0.00 & 0.68 & 6.06 & 22.28 \\
\hline 11. & Nov & 0.00 & 0.00 & 1.71 & 32.10 & 154.56 \\
\hline 12. & Dec & 0.00 & 0.00 & 14.11 & 92.83 & 532.77 \\
\hline
\end{tabular}

Station; and from $0.30 \mathrm{ML} / \mathrm{d}$ at the Discharge Site). Boxplots in Figure 6 for the flows recorded at the Forestry Station further illustrate the described monthly variability.

The 90th percentiles would range from
Table 3 - Flow percentiles (ML/d) at Discharge Site

\begin{tabular}{|l|c|c|c|c|c|c|}
\hline № & Month & $\begin{array}{c}5 \text { th } \\
\text { \%ile }\end{array}$ & $\begin{array}{c}50 \text { th } \\
\text { \%ile }\end{array}$ & $\begin{array}{c}\text { 75th } \\
\text { \%ile }\end{array}$ & $\begin{array}{c}\text { 90th } \\
\% \text { ile }\end{array}$ & $\begin{array}{c}95 \text { th } \\
\% \text { ile }\end{array}$ \\
\hline 1. & Jan & 0.00 & 0.00 & 0.36 & 3.47 & 9.83 \\
\hline 2. & Feb & 0.00 & 0.01 & 0.45 & 2.97 & 10.31 \\
\hline 3. & Mar & 0.00 & 0.00 & 0.30 & 1.33 & 6.06 \\
\hline 4. & Apr & 0.00 & 0.00 & 0.02 & 0.38 & 1.78 \\
\hline 5. & May & 0.00 & 0.00 & 0.03 & 0.32 & 1.07 \\
\hline 6. & Jun & 0.00 & 0.00 & 0.01 & 0.25 & 0.78 \\
\hline 7. & Jul & 0.00 & 0.00 & 0.02 & 0.29 & 0.70 \\
\hline 8. & Aug & 0.00 & 0.00 & 0.02 & 0.29 & 0.80 \\
\hline 9. & Sep & 0.00 & 0.00 & 0.06 & 0.43 & 0.92 \\
\hline 10. & Oct & 0.00 & 0.00 & 0.02 & 0.16 & 0.59 \\
\hline 11. & Nov & 0.00 & 0.00 & 0.05 & 0.85 & 4.11 \\
\hline 12. & Dec & 0.00 & 0.00 & 0.38 & 2.47 & 14.18 \\
\hline
\end{tabular}

11.51 ML/d (October, Table 1) to $247.74 \mathrm{ML} / \mathrm{d}$ (January, Table 1) at the Forestry Station; from $6.06 \mathrm{ML} / \mathrm{d}$ to $130.36 \mathrm{ML} / \mathrm{d}$ at the Middle Station (

Table 2); and from $0.16 \mathrm{ML} / \mathrm{d}$ to $3.47 \mathrm{ML} / \mathrm{d}$ at the Discharge Site (Table 3). The lowest 90th percentile values were obtained for the months from April through to October (up to $30.84 \mathrm{ML} / \mathrm{d}$ (September, Table 1) at the Forestry Station, up to $16.23 \mathrm{ML} / \mathrm{d}$ at the Middle Station, and up to $0.43 \mathrm{ML} / \mathrm{d}$ at the Discharge Site). The values higher than $61.00 \mathrm{ML} / \mathrm{d}$, $32.00 \mathrm{ML} / \mathrm{d}$, and $0.85 \mathrm{ML} / \mathrm{d}$ would be in the months from November through to March at the Forestry Station, Middle Station, and Discharge Site respectively.

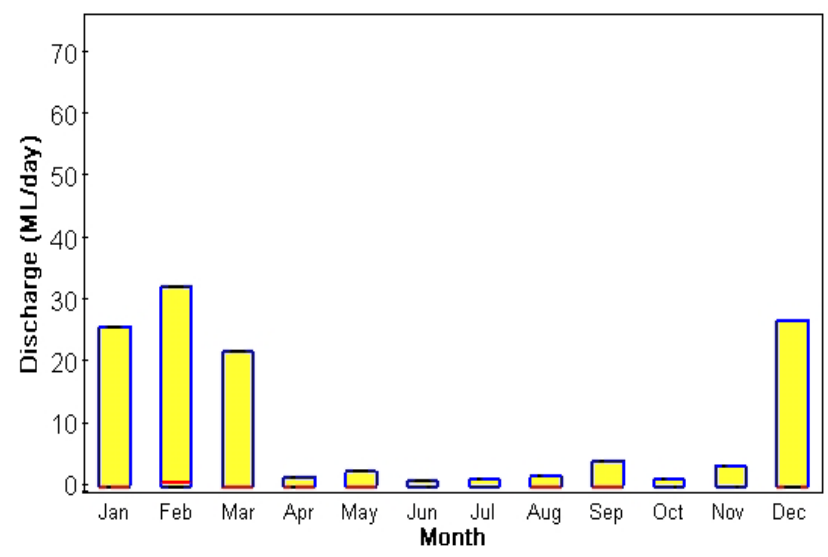

Figure 6 - Boxplot representation of 25th, 50th and 75th percentiles for flows at Forestry Station

The 95th percentile estimates ranged from 
42.34 ML/d (October, Table 1) to $1012.26 \mathrm{ML} / \mathrm{d}$ (December, Table 1) at the Forestry Station; from 22.28 ML/d to $532.77 \mathrm{ML} / \mathrm{d}$ at the Middle Station (Table 2); and from $0.59 \mathrm{ML} / \mathrm{d}$ to $14.18 \mathrm{ML} / \mathrm{d}$ at the Discharge Site (Table 3). The lowest 95th percentiles were obtained for the months from May through to October (up to $76.31 \mathrm{ML} / \mathrm{d}$ (May, Table 1) at the Forestry Station, up to $40.16 \mathrm{ML} / \mathrm{d}$ at the Middle Station, and up to $1.07 \mathrm{ML} / \mathrm{d}$ at the Discharge Site). The values higher than 126.90 ML/d (April, Table 1), 66.79 ML/d, and $1.78 \mathrm{ML} / \mathrm{d}$ would be in the months from November through to April at the Forestry Station, Middle Station, and Discharge Site respectively.

After $40 \mathrm{ML} / \mathrm{d}$ from the Reedy Creek WTF was added to the Yuleba Creek flows, the 5th, 50th, 75th, 90th and 95th percentiles were recalculated; the results are presented in Table 4 , Table 5, and Table 6 .

An analysis of the tables suggests that the most affected would be the 5 th and the 50th percentile values, which would all stagger between 40.00 and $40.69 \mathrm{ML} / \mathrm{d}$ at all three of the considered sites. A comparison of Table 3 and Table 6 suggests that the WTF discharge would constitute the larger part of all flows at the Discharge Site.

The 75th percentile flows would increase by the factor from 2.2 (see data for February in Table 1 and Table 4) to 40.2 (see data for June in Table 1 and

Table 4 -Flow with added $40 \mathrm{ML} / \mathrm{d}$ discharge from Reedy Creek WTF percentiles (ML/d) at Forestry Station

\begin{tabular}{|l|c|c|c|c|c|c|}
\hline № & Month & $\begin{array}{c}5 \text { th } \\
\text { \%ile }\end{array}$ & $\begin{array}{c}\text { 50th } \\
\text { \%ile }\end{array}$ & $\begin{array}{c}75 \text { th } \\
\text { \%ile }\end{array}$ & $\begin{array}{c}\text { 90th } \\
\text { \%ile }\end{array}$ & $\begin{array}{c}\text { 95th } \\
\text { \%ile }\end{array}$ \\
\hline 1. & Jan & 40.00 & 40.00 & 65.82 & 287.75 & 742.27 \\
\hline 2. & Feb & 40.00 & 40.69 & 72.25 & 251.87 & 776.37 \\
\hline 3. & Mar & 40.00 & 40.09 & 61.78 & 134.65 & 472.66 \\
\hline 4. & Apr & 40.00 & 40.00 & 41.64 & 66.79 & 166.90 \\
\hline 5. & May & 40.00 & 40.00 & 42.47 & 62.76 & 116.31 \\
\hline 6. & Jun & 40.00 & 40.00 & 41.02 & 57.89 & 95.58 \\
\hline 7. & Jul & 40.00 & 40.00 & 41.28 & 60.70 & 90.29 \\
\hline 8. & Aug & 40.00 & 40.00 & 41.73 & 60.71 & 97.37 \\
\hline 9. & Sep & 40.00 & 40.00 & 44.15 & 70.85 & 105.39 \\
\hline 10. & Oct & 40.00 & 40.00 & 41.30 & 51.51 & 82.34 \\
\hline 11. & Nov & 40.00 & 40.00 & 43.24 & 101.00 & 333.59 \\
\hline 12. & Dec & 40.00 & 40.00 & 66.81 & 216.41 & 1052.14 \\
\hline
\end{tabular}

Table 5 - Flow with added $40 \mathrm{ML} / \mathrm{d}$ discharge from Reedy Creek WTF percentiles (ML/d) at Middle Station

\begin{tabular}{|l|c|c|c|c|c|c|}
\hline № & Month & $\begin{array}{c}\text { 5th } \\
\text { \%ile }\end{array}$ & $\begin{array}{c}50 \text { th } \\
\text { \%ile }\end{array}$ & $\begin{array}{c}75 \text { th } \\
\text { \%ile }\end{array}$ & $\begin{array}{c}\text { 90th } \\
\text { \%ile }\end{array}$ & $\begin{array}{c}95 \text { th } \\
\text { \%ile }\end{array}$ \\
\hline 1. & Jan & 40.00 & 40.00 & 53.59 & 170.36 & 409.60 \\
\hline 2. & Feb & 40.00 & 40.37 & 56.98 & 151.55 & 427.57 \\
\hline 3. & Mar & 40.00 & 40.05 & 51.46 & 89.79 & 267.69 \\
\hline 4. & Apr & 40.00 & 40.00 & 40.87 & 54.10 & 106.81 \\
\hline 5. & May & 40.00 & 40.00 & 41.30 & 51.98 & 80.16 \\
\hline 6. & Jun & 40.00 & 40.00 & 40.54 & 49.41 & 69.26 \\
\hline 7. & Jul & 40.00 & 40.00 & 40.67 & 50.90 & 66.47 \\
\hline 8. & Aug & 40.00 & 40.00 & 40.91 & 50.90 & 70.20 \\
\hline 9. & Sep & 40.00 & 40.00 & 42.19 & 56.24 & 74.41 \\
\hline 10. & Oct & 40.00 & 40.00 & 40.69 & 46.06 & 62.28 \\
\hline 11. & Nov & 40.00 & 40.00 & 41.71 & 72.11 & 194.56 \\
\hline 12. & Dec & 40.00 & 40.00 & 54.11 & 132.83 & 572.77 \\
\hline
\end{tabular}

Table 6 - Flow with added $40 \mathrm{ML} / \mathrm{d}$ discharge from Reedy Creek WTF percentiles (ML/d) at Discharge Site

\begin{tabular}{|l|c|c|c|c|c|c|}
\hline № & Month & $\begin{array}{c}5 \text { th } \\
\text { \%ile }\end{array}$ & $\begin{array}{c}50 \text { th } \\
\text { \%ile }\end{array}$ & $\begin{array}{c}75 \text { th } \\
\text { \%ile }\end{array}$ & $\begin{array}{c}\text { 90th } \\
\text { \%ile }\end{array}$ & $\begin{array}{c}95 \text { th } \\
\text { ile }\end{array}$ \\
\hline 1. & Jan & 40.00 & 40.00 & 40.37 & 43.47 & 49.84 \\
\hline 2. & Feb & 40.00 & 40.01 & 40.46 & 42.97 & 50.31 \\
\hline 3. & Mar & 40.00 & 40.00 & 40.31 & 41.33 & 46.07 \\
\hline 4. & Apr & 40.00 & 40.00 & 40.03 & 40.37 & 41.78 \\
\hline 5. & May & 40.00 & 40.00 & 40.04 & 40.32 & 41.07 \\
\hline 6. & Jun & 40.00 & 40.00 & 40.02 & 40.25 & 40.78 \\
\hline 7. & Jul & 40.00 & 40.00 & 40.02 & 40.29 & 40.71 \\
\hline 8. & Aug & 40.00 & 40.00 & 40.03 & 40.29 & 40.81 \\
\hline 9. & Sep & 40.00 & 40.00 & 40.06 & 40.44 & 40.92 \\
\hline 10. & Oct & 40.00 & 40.00 & 40.02 & 40.17 & 40.60 \\
\hline 11. & Nov & 40.00 & 40.00 & 40.05 & 40.86 & 44.11 \\
\hline 12. & Dec & 40.00 & 40.00 & 40.38 & 42.47 & 54.18 \\
\hline
\end{tabular}

Table 4) at the Forestry Station; by the factor from 3.4 to 94.3 at the Middle Station (see Table 2 and Table 5 for June and February respectively); and by the factor from 89.9 to 4002.0 at the Discharge Site (see Table 3 and Table 6 for the same months as mentioned above). Boxplots in Figure 7 illustrate 
the described monthly variability for the Forestry Station flows.

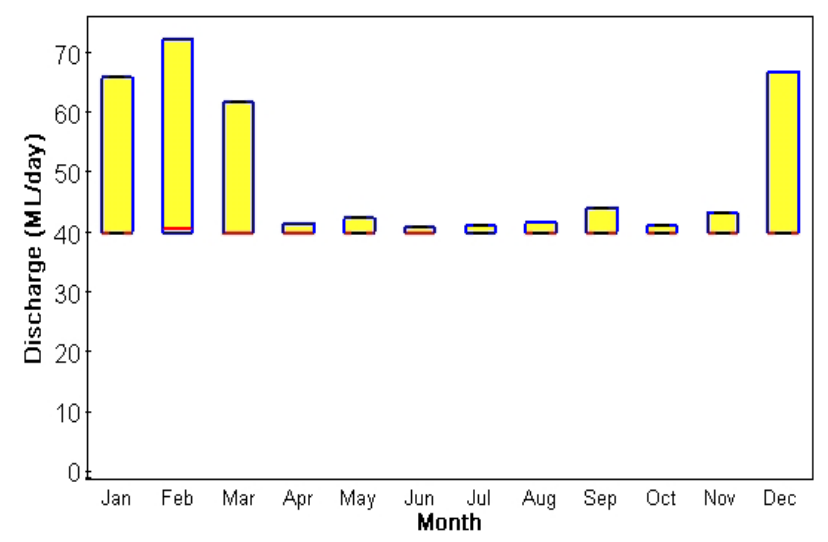

Figure 7 - Boxplot representation of 25th, 50th and 75th percentiles for flows at Forestry Station with added $40 \mathrm{ML} / \mathrm{d}$ Reedy Creek WTF discharge

The 90th percentile flows would increase by the factor from 1.2 (see data for January in Table 1 and Table 4) to 4.5 (see data for October in Table 1 and Table 4) at the Forestry Station; by the factor from 1.3 to 7.6 at the Middle Station (see January and October respectively in Table 2 and Table 5); and by the factor from 12.5 to 215.1 at the Discharge Site (see Table 3 and Table 6 for the same months as above).

The 95th percentile flows would increase by the factor from 1.04 (see data for December in Table 1 and Table 4) to 1.9 (see data for October in Table 1 and Table 4) at the Forestry Station; by the factor from 1.1 to 2.8 at the Middle Station (see December and October in Table 2 and Table 5); and by the factor from 3.8 to 68.8 at the Discharge Site (see Table 3 and Table 6 for the same months as above).

Flow exceedance probabilities for the historical and scaled discharges at the three study locations are presented in Figure 8 and Figure 9. An analysis of the figures suggests that, based on the historical data, the annually averaged flow of $0.08 \mathrm{ML} / \mathrm{d}$ (coloured solid lines in the figures) in the Yuleba Creek would be present for around $48 \%$ of the time at the Forestry Station gauge, for around $45 \%$ of the time at the Middle Station location, and around 32\% of the time at the Discharge Site location.

For the months of December, January and February, which were identified as the wettest, the exceedance probabilities of $0.08 \mathrm{ML} / \mathrm{d}$ flows would respectively be around $52 \%$, around $56 \%$ and around $62 \%$ at both the Forestry and the Middle Stations, and around $44 \%$ at the Discharge Site (see Figure 8).

For the months of May, June and July, which were identified as the driest, the exceedance prob- abilities of $0.08 \mathrm{ML} / \mathrm{d}$ flows would respectively be around $36 \%$, around $40 \%$ and around $42 \%$ at both the Forestry and the Middle Stations, and around $28 \%$, around $26 \%$ and around $32 \%$ at the Discharge Site (see Figure 9). The figure indicates that compared to the annual there will be a significant drop in exceedance probabilities for dry season flows of $1.00 \mathrm{ML} / \mathrm{d}$, which will be in the range from $7 \%$ to $10 \%$ at the Discharge Site.

Exceedance probabilities accounting for the planned $40 \mathrm{ML} / \mathrm{d}$ discharge from the Reedy Creek WTF in Figure 10 and Figure 11 suggest that the seasonal variability at all three of the study sites will essentially be smoothed and levelled at the WTF discharge capacity.

\subsection{Predictability}

Flow predictability has two separable components, which are constancy and contingency. When used in the flow analysis, the components are defined as follows. Constancy is a measure of the degree the flows are constant. Contingency is a measure of the degree the annual pattern of repeating.

Predictability may range from 0 to 1 . A pattern of flow is designated minimally predictable (predictability equal 0 ) if all states of flow are equally likely for all times, thus it cannot be predicted. The pattern is maximally predictable (predictability equal 1) if the flow stays the same for a time period in all years under consideration.

Flows predictabilities were calculated for the historical gauge records and for the modified with the planned Reedy Creek WTF discharge flows.

The parameter of predictability is estimated based on the flow magnitude comparisons. Therefore, scaling of the Forestry Station gauge records would not affect the estimates of this parameter for the Middle Station and Discharge Site locations, and only Forestry Station results are presented here. For the historical records, the value of predictability was 0.50 , and the constancy/predictability ratio was 0.89 .

For the modified flows, the values of predictability change from location to location because the relative input of the constant discharge into the total flow at a specific location was different. At the Forestry Station, predictability was 0.62 , and the constancy/predictability ratio was 0.94 ; at the Middle Station, predictability was 0.74 , and the constancy/predictability ratio was 0.95 ; at the Discharge Site, predictability was 0.85 , and the constancy/predictability ratio was 0.98 . 

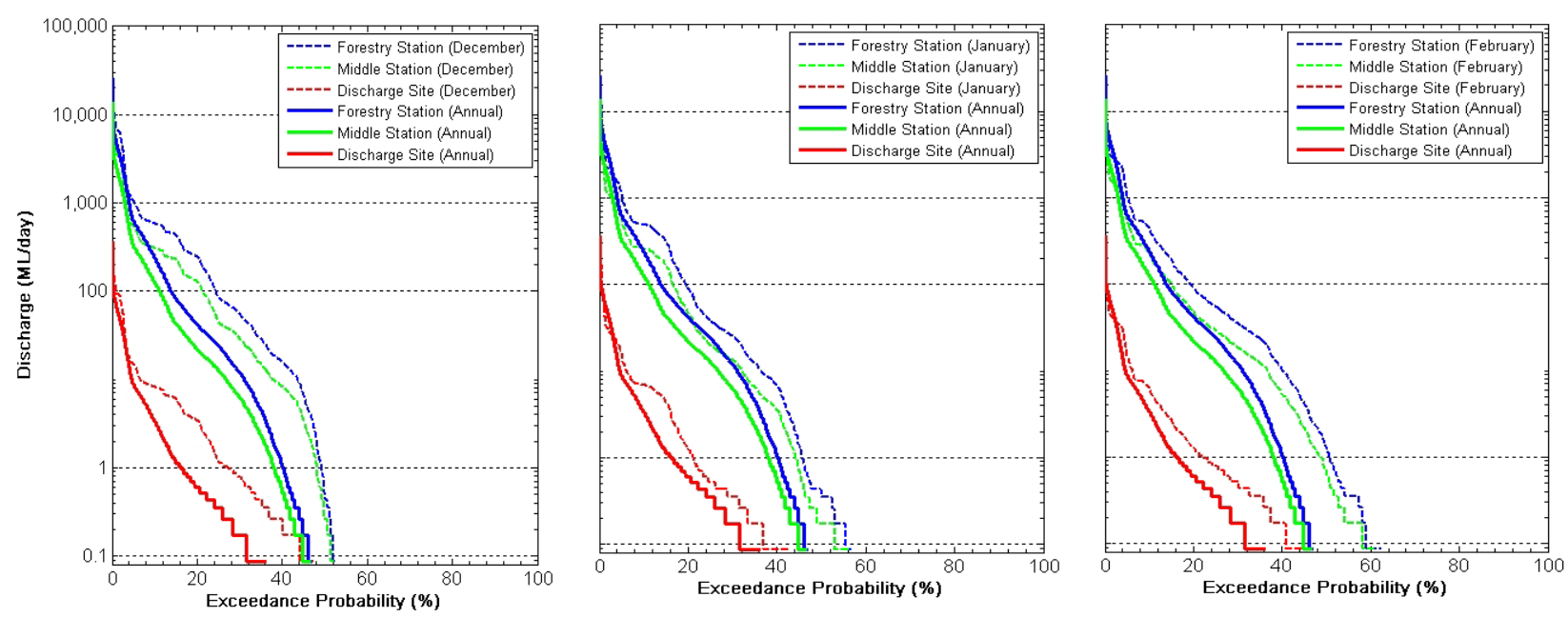

Figure 8 - Exceedance probabilities estimated at three study locations for wettest months of December (left panel), January (middle panel) and February (right panel)
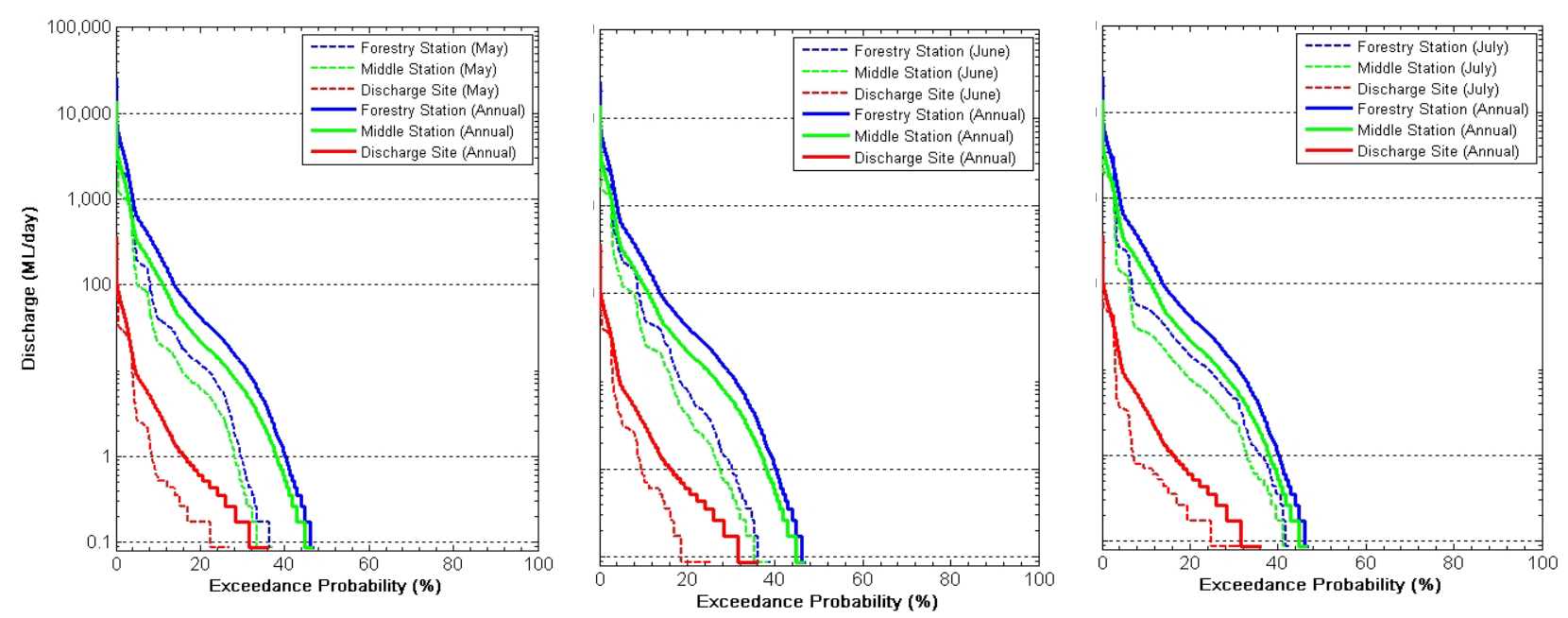

Figure 9 - Exceedance probabilities estimated at three study locations for driest months of May (left panel), June (middle panel) and July (right panel)
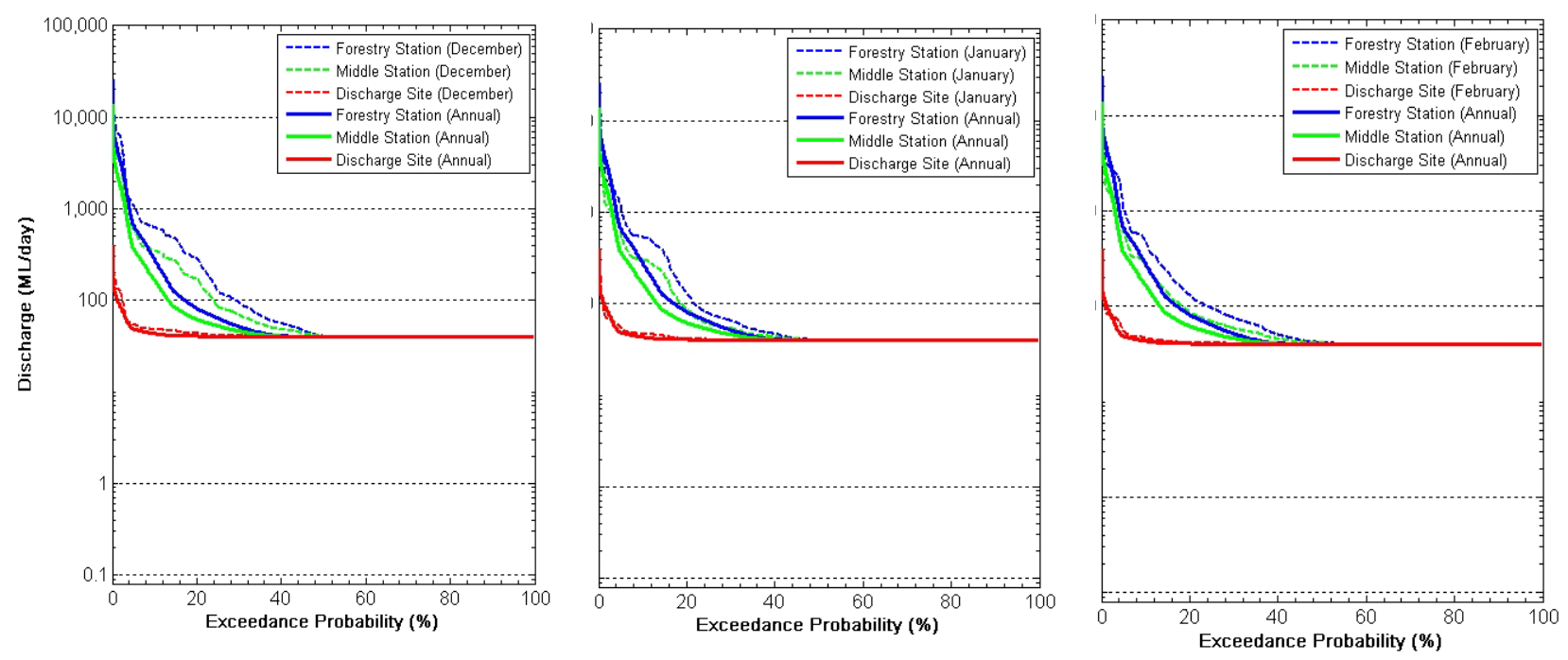

Figure 10 - Exceedance probabilities accounting for $40 \mathrm{ML} / \mathrm{d}$ discharge from Reedy Creek WTP estimated at three study locations for wettest months of December (left panel), January (middle panel) and February (right panel) 

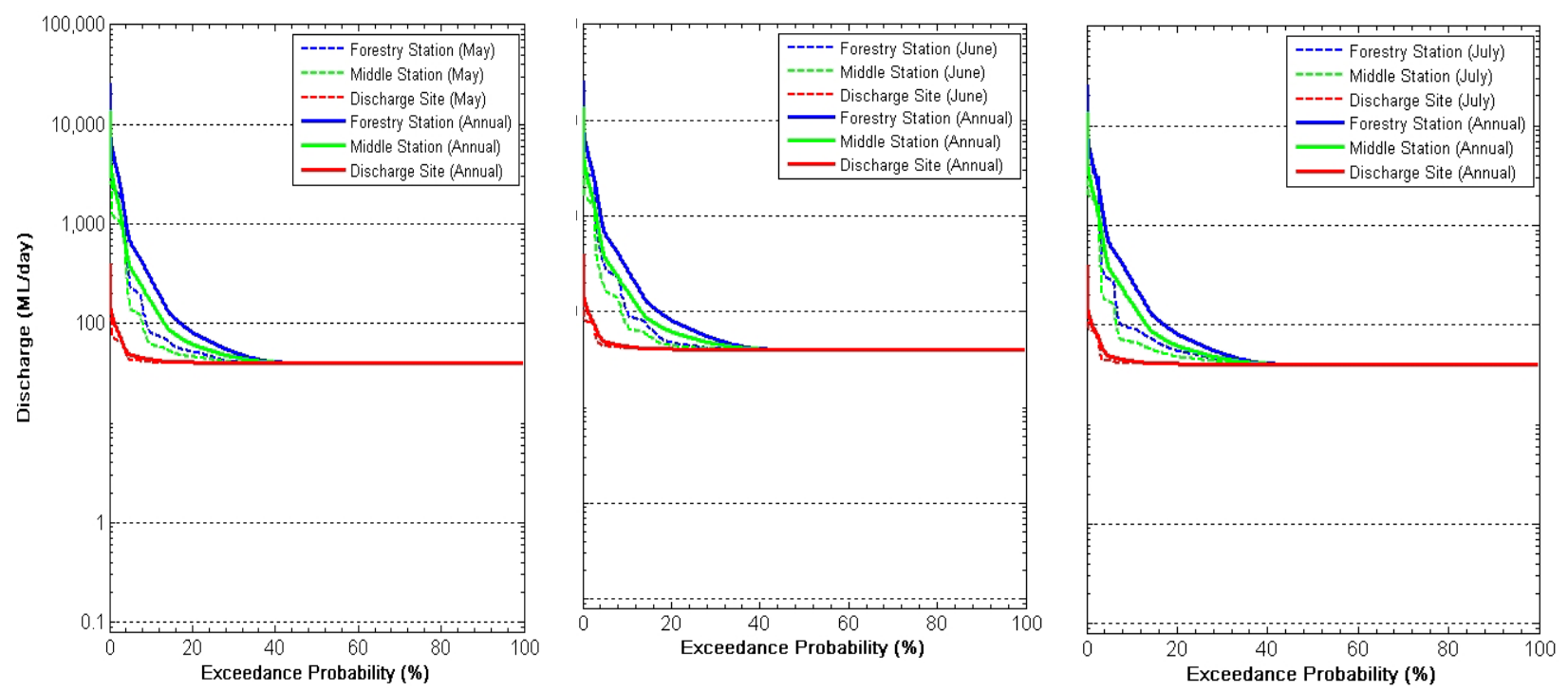

Figure 11 - Exceedance probabilities accounting for 40 ML/d discharge from Reedy Creek WTP estimated at three study locations for driest months of May (left panel), June (middle panel) and July (right panel)

\subsection{Rates of rise and fall}

The rates of streamflow rise were estimated as the median of all positive differences between consecutive daily flow values. Similarly, the rates of fall were estimated as the median of all negative differences between consecutive daily values. Therefore, the magnitudes of these parameters estimated for the historical records and for the data accounting for the $40 \mathrm{ML} / \mathrm{d}$ Reedy Creek WTF discharge were exactly the same.

The obtained estimates for rates of rise and fall are presented in Figure 12 and Figure 13 respectively.
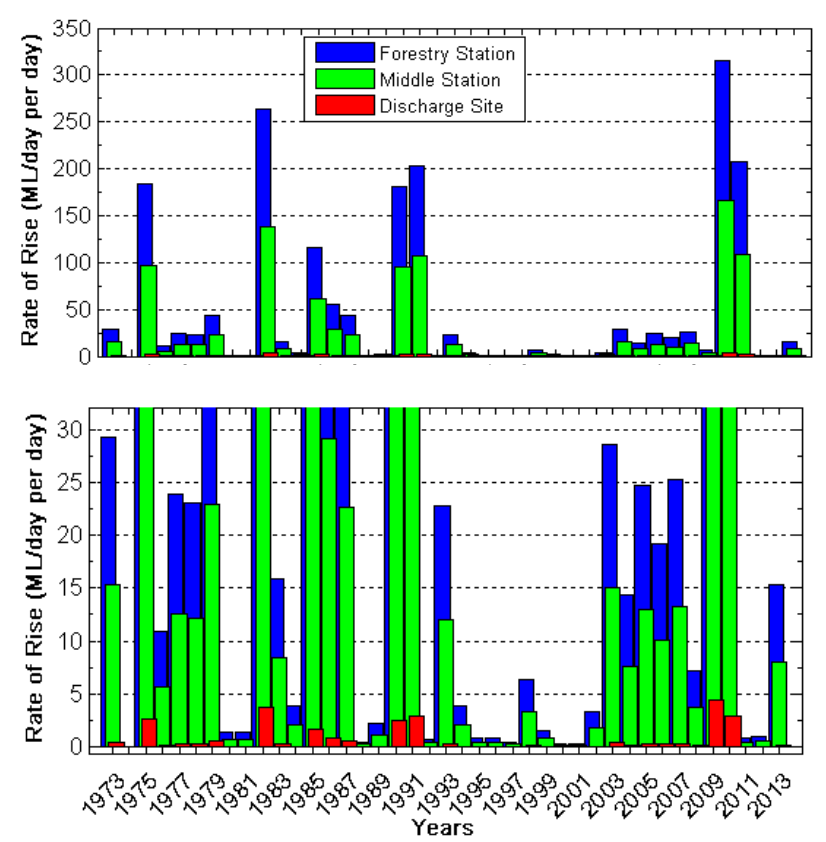

Figure 12 - Rates of rise (entire range in top panel and zoomed view in bottom panel) estimated at three study locations
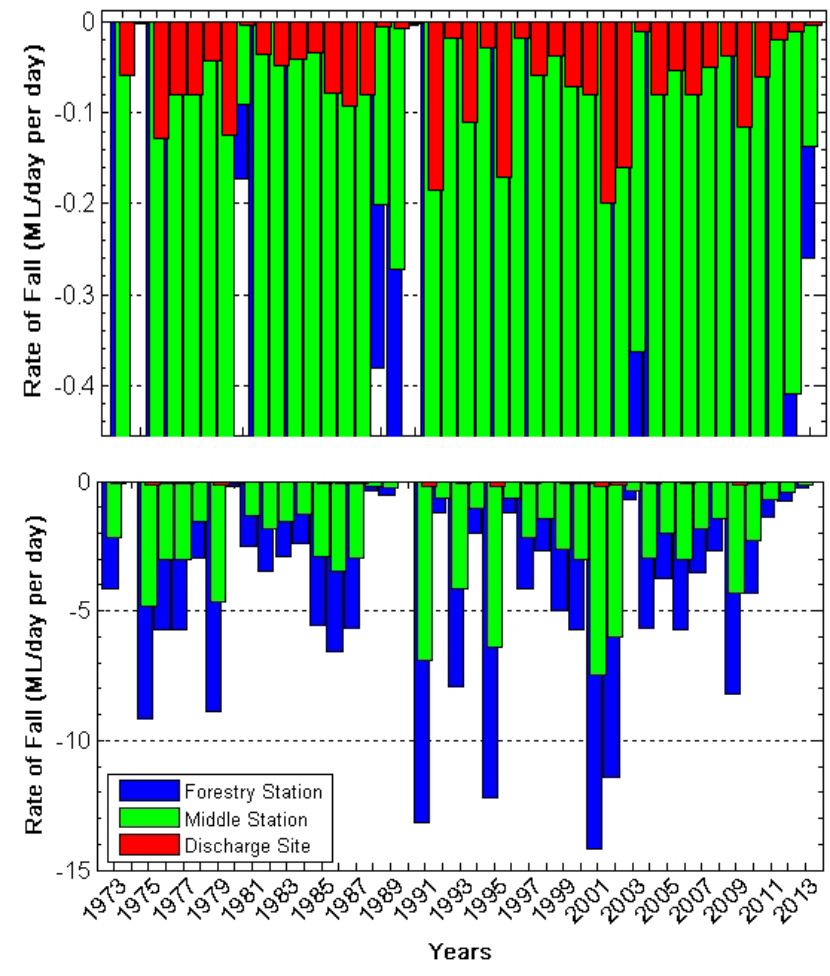

Figure 13 - Rates of fall (zoomed view in top panel and entire range in bottom panel) estimated at three study locations

An analysis of the figures suggests that the rate of streamflow rise varied within a range from 0.0 up to $320.0 \mathrm{ML} / \mathrm{d}$ per day at the Forestry Station, up to 160.0 ML/d per day at the Middle Station, and up to 5.0 ML/d per day at the Discharge Site.

The rate of streamflow fall had a significantly smaller ranges: up to $15.0 \mathrm{ML} / \mathrm{d}$ per day at the Forestry Station, up to $7.5 \mathrm{ML} / \mathrm{d}$ per day at the Middle 
Station, and up to $0.2 \mathrm{ML} / \mathrm{d}$ per day at the Discharge Site.

To complement the above data, a number of high flow pulses per year over the period of the historical records is presented in Figure 14. For all the stations these data were obviously the same.

The figure suggests that there may be up to 4-5 high flow pulses within an average year. Over the analysed period however there were 5 years with 8 and higher number of pulses.

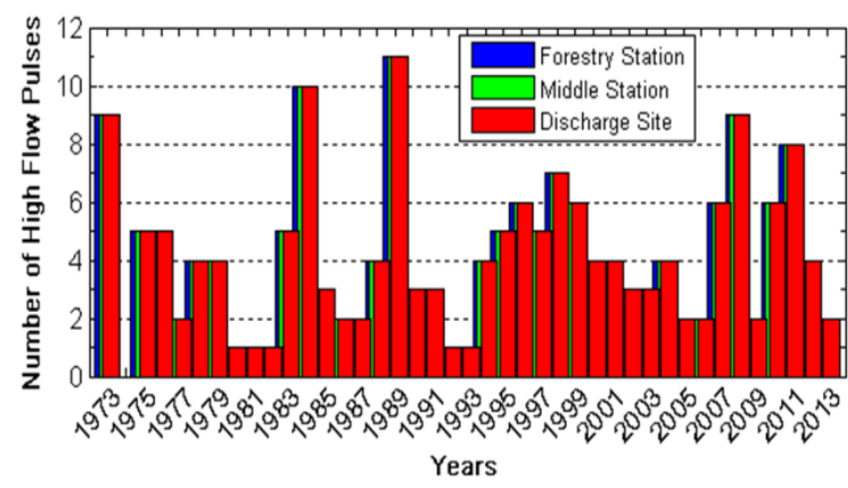

Figure 14 - Number of high flow pulses estimated at three study locations

\section{CONCLUDING REMARKS}

The historical maximum flow was $25,825 \mathrm{ML} / \mathrm{d}$.

Years 1983, 1999, and 2010-2012 had the highest median flows of around $15 \mathrm{ML} / \mathrm{d}, 10 \mathrm{ML} / \mathrm{d}$, and from $9 \mathrm{ML} / \mathrm{d}$ to $12 \mathrm{ML} / \mathrm{d}$ respectively. It was indicated that the median flow values would only exceed from $0.09 \mathrm{ML} / \mathrm{d}$ to $0.69 \mathrm{ML} / \mathrm{d}$ during the months of February and March.

The lowest 90th percentile flows were obtained for the months from April through to October. The highest flow estimates would be in the months from November through to March.

An analysis of the flow duration curves suggested that the annually averaged flow of $0.08 \mathrm{ML} / \mathrm{d}$ in the Yuleba Creek would be present for around $48 \%$ of the time.
For the baseline flow records, the value of predictability was 0.50 , and the constancy / predictability ratio was 0.89 .

The rates of streamflow rise and fall were estimated and analysed. The results suggested that the rate of streamflow rise varied within a range from 0.0 up to $320.0 \mathrm{ML} / \mathrm{d}$ per day. The rates of streamflow fall was up to $15.0 \mathrm{ML} / \mathrm{d}$ per day.

A number of high flow pulses per year over the period of the historical records was on average from 4 to 5 , with the maximum value of 11 .

\section{ACKNOWLEDGMENTS}

The coal seam gas project operator is acknowledged for providing discharge input data used in this study.

\section{REFERENCES}

1. McGregor, M. \& Takahashi, A. (2011). Healthy Headwaters Coal Seam Gas Water Feasibility Study Activity 4: Stream Ecosystem Health Response to Coal Seam Gas Water Release Guideline for Managing Flow Regimes. Available at: http://research.ccsg.uq.edu.au/ projects/healthy-headwaters-coal-seam-gas-water-

feasibility-study) (Accessed: 22.04.1019)

2. Gordon, N.D. et al. (2013). Stream Hydrology: An Introduction for Ecologists. John Wiley \& Sons.

3. Poff, N.L. \& Ward, J.V. (1989). Implications of streamflow variability and predictability for lotic community structure: a regional analysis of streamflow patterns. Canadian Journal of Fisheries and Aquatic Sciences, 46, pp. 18051818.

4. Marsh, N. (2004). RAP river analysis package: user guide, version 1.1. CRC for Catchment Hydrology, Australia, Jan 2004. Available at: www.toolkit.net.au/rap (Accessed: 21.03.1019)

5. Kennard, M.J. et al. (2008). Appendix 5: Ecohydrological classification of Australia's flow regimes.

6. She, D., Xia, J., Zhang, Y. \& Shan, L. (2016). Regional Frequency Analysis of Extreme Dry Spells during Rainy Season in the Wei River Basin, China. Advances in Meteorology, 2016, Article ID 6427568, http://dx.doi.org/ $10.1155 / 2016 / 6427568$.

7. Murray-Darling Basin Authority for and on behalf of the Commonwealth of Australia. (2012). Hydrologic modelling of the relaxation of operational constraints in the southern connected system: Methods and results.

\title{
ДОВГОСТРОКОВИЙ АНАЛІЗ (SPELLS ANALYSIS) РЕЖИМУ ПРИРОДНОГО СТОКУ ДЛЯ СКИДІВ ОЧИЩЕНИХ ВОД
}

\author{
Олег Макаринський, \\ Діна Макаринська \\ Metocean Dynamic Solutions, \\ 9 Seale Street, Fannie Bay, 0820 NT, Australia, makarynskyy@outlook.com
}

Для проведення заходів з видобутку корисних копалин зазвичай потрібно отримати
набір дозволів на кожен із запланованих заходів, які будуть здійснюватися. Це 
безпосередньо стосується управління водними ресурсами та скидами, пов'язаними з будьякими операціями з видобутку корисних копалин. У відповідь на зростаючий попит на енергоресурси в усьому світі, різко збільшився попит у галузі на отримання дозволів на видобуток газу з вугільних пластів та сланцевого газу. Це, в свою чергу, супроводжується занепокоєністю громадськості щодо практики гідравлічного розриву пластів порід та очищення використаної/відпрацьованої води.

Для вирішення цих проблем державними органами Австралії розроблені чіткі норми та керівні принципи щодо процесу подання заявок на отримання дозволу і надання технічного завдання для оцінки впливу на навколишне середовище, де це потрібно. Відповідно до настанов, оператор 3 видобутку скрапленого природного газу проводив дослідження 3 метою оцінки кількох аспектів скиду води у річку Юлба з очисних споруд Ріді Крік, штат Квінсленд. Дослідження виконувались відповідно до настанов і включали оцінку найменшого стоку з декількох можливих об'ємів скиду води з водоочисних споруд протягом запланованого для скидів періоду. Мета дослідження, описаного у цій роботі, полягала в тому, щоб оцінити стік річки Юлба до та після ймовірних скидів очищеної води 3 водоочисної споруди Ріді Крік та те, як запланована зміна параметрів стоку буде відповідати нормативним настановам. Оцінка грунтувалася на даних за 41 рік, зібраних на водовимірювальній станції Форестрі.

Аналіз отриманих результатів свідчить, що історичний максимум становив 25825 Мл/д. Аналіз медіанного стоку показав, що у 1983, 1999 та 2010-2012 роках найвищі медіани становили приблизно 15 Мл/д, 10 Мл/д та від 9 Мл/д до 12 Мл/д, відповідно. Медіанні значення стоку перевищували від 0,09 Мл/д до 0,69 Мл/д лише у лютому та березні. Нижчий стік 90-го процентиля був отриманий у місяці 3 квітня по жовтень. Найвищі оцінки значень стоку були отримані в період 3 листопада до березня. Аналіз кривих тривалості стоку показав, що середньорічні витрати 0,08 Мл/д буде присутній протягом приблизно 48\% часу. Розраховувалась прогнозованість стоку. Для записів витрат базового потоку значення передбачуваності становило 0,50 , а співвідношення сталість/передбачуваність становило 0,89. Також оцінювалась та аналізувалась швидкість зростання та зниження стоку. Результати показали, що прискорення зростання потоку змінювалося в межах від 0,0 до 320,0 Мл/д за добу. Прискорення зменшення потоку становило до 15,0 Мл/д за добу.

Ключові слова: видобуток вугільного газу; управління водними ресурсами; параметри стоку; величина стоку; мінливість стоку; передбачуваність стоку; прискорення зростання та зменшення збільшеного стоку.

\title{
ДОЛГОСРОЧНЫЙ АНАЛИЗ (SPELLS ANALYSIS) РЕЖИМА ПРИРОДНОГО СТОКА ДЛЯ СБРОСОВ ОЧИЩЕННЫХ ВОД
}

\author{
Олег Макаринский, \\ Дина Макаринская \\ Metocean Dynamic Solutions, \\ 9 Seale Street, Fannie Bay, 0820 NT, Australia, makarynskyy@outlook.com
}

Добыча полезных ископаемых обычно требует получения набора разрешений для каждой из запланированных работ. Это непосредственно касается управления водными ресурсами и сбросами, связанными с любыми операциями по добыче полезных ископаемых. В ответ на растущий спрос на энергоресурсы во всем мире, спрос в промышленности на разрешения, связанные с добычей природного газа из угольных пластов и сланцевого газа, также резко возрос. Это, в свою очередь, сопровождается растущей обеспокоенностью общественности относительно практики гидравлического разрыва пластов породы и очистки использованной/отработанной воды.

Для решения этих проблем органами государственного управления в Австралии разработаны строгие нормы и руководящие принципы для процесса подачи заявок и предоставления технического задания для оценки воздействия на окружающую среду, где это необходимо. В соответствии с руководящими принципами, оператор по добыче сжиженного природного газа проводил исследование для оценки нескольких аспектов сброса воды в реку Юлба из водоочистного сооружения Риди Крик, штат Квинсленд. Исследования производились в соответствии с руководящими принципами и включали 
оценку наименьшего стока при нескольких возможных объемах сбросов с водоочистных сооружений в течение планируемого периода сбросов. Цель исследования, представленного в этой статье, состояла в том, чтобы оценить сток реки Юлба до и после предполагаемых сбросов очищенной воды с водоочистного сооружения Риди Крик, а также то, как планируемое изменение параметров стока будет соответствовать нормативным руководящим принципам. Оценка была основана на данных за 41 год с водомерной станции Форестри.

Анализ полученных результатов показал, что исторический максимум составлял 25825 Мл/сут. Анализ медианных значений стока показал, что в 1983, 1999 и 2010-2012 годах самые высокие медианы составляли около 15 Мл/сут, 10 Мл/сут и от 9 до 12 Мл/сут, соответственно. Медианные значения стока превышали от 0,09 Мл/сут до 0,69 Мл/сут только в феврале и марте. Самый малый сток 90-го процентиля был получен в месяцы с апреля по октябрь. Самые высокие оценки значений стока были получены в период с ноября до марта. Анализ кривых продолжительности стока показал, что среднегодовой расход 0,08 Мл/сут будет присутствовать в течение примерно $48 \%$ времени. Была рассчитана предсказуемость стока. Для записей расхода базового потока значение предсказуемости составило 0,50, а отношение постоянства/предсказуемости составило 0,89 . Скорость возрастания и снижения стока также была оценена и проанализирована. Результаты показали, что ускорение возрастания потока колебалось в диапазоне от 0,0 до 320,0 Мл/сут за сутки. Ускорение снижения потока составляла до 15,0 Мл/сут за сутки.

Ключевые слова: добыча газа из угольных пластов; управление водными ресурсами; параметры стока; величина стока; изменчивость стока; предсказуемость стока; ускорение возрастания и снижения увеличенного стока. 